\title{
PUBLICZNE PREZENTOWANIE ZDJĘĆ MARTWYCH PLODÓW JAKO WYBRYK ZAKŁÓCENIA SPOKOJU I PORZĄDKU PUBLICZNEGO BĄDŹ WYWOLANIA ZGORSZENIA (ART. 51 § 1 KODEKSU WYKROCZEŃ)
}

\section{WSTEPP}

Jednym ze sposobów zwrócenia uwagi na prezentowane poglądy jest posługiwanie się przez działaczy Pro-life ${ }^{1}$ publicznie barwnymi, nierzadko wielkoformatowymi zdjęciami zakrwawionych, martwych płodów ludzkich, niekiedy rozczłonkowanych. Zachowania takie podlegaja karze z art. 140 Kodeksu wykroczeń $^{2}$, jako tzw. nieobyczajny wybryk, albo z art. 141 k.w. ${ }^{3}$ Jeśli jednak nastapi skutek w postaci zakłócenia porządku lub spokoju publicznego bądź wywołania zgorszenia w miejscu publicznym, właściwa jest kwalifikacja z art. $51 \S 1$ k.w.

\section{II. ŹRÓDŁA ART. 28 PRAWA O WYKROCZENIACH Z 1932 ROKU}

Obowiązujący art. $51 \S 1$ k.w. bierze swój początek w głównej mierze ${ }^{4}$ w art. 262 rosyjskiego kodeksu karnego z 1903 r. (dalej - r.k.k.), otwierajacym Rozdział XII: „O pogwałceniu przepisów, ochraniających spokój publiczny”. W interesujacym nas zakresie przepis ten brzmiał: „Winny hałasu, krzyku lub innego wybryku w miejscu publicznem lub na zebraniu publicznem, albo wprawdzie poza niemi, lecz z zakłóceniem porządku lub spokoju publicznego, będzie karany [...]”. Przepis ten miał za przedmiot ochrony „spokój lub porzą-

${ }^{1}$ Przede wszystkim z Fundacji Pro - Prawo do Życia. Poniższe uwagi maja jednak charakter uniwersalny i odnoszą się do każdego przypadku posługiwania się wskazanymi zdjęciami.

${ }^{2}$ Ustawa z 20 maja 1971 r. - Kodeks wykroczeń, t.jedn.: Dz. U. 2018, poz. 618 ze zm. (dalej jako: k.w.).

${ }^{3}$ Podstawy tych kwalifikacji zostały wykazane w: Kulesza (2019b); (2020b); (2019a); (2020a), brak zaś naruszenia prawa do wolności wypowiedzi w przypadku skazania z art. 140, 141 albo 51 k.w. (Kulesza 2020c).

${ }^{4}$ Falandysz (1974): 27. Czerpano inspirację również z prawa francuskiego, niemieckiego, szwajcarskiego i czechosłowackiego, por. Rappaport (1929); Rappaport, Lemkin (1931).

${ }_{5}$ Tekst w tłumaczeniu A. Mogilnickiego i E.S. Rappaporta za tekstem „dosłownego przekładu urzędowego Ministerstwa Sprawiedliwości z r. 1922” (Mogilnicki, Rappaport (1928): V, 244-245); 
dek publiczny”, który to porządek definiowano jako „uregulowany według pewnych zasad wzajemny stosunek zewnętrzny ludzi lub rzeczy”. Ów „inny wybryk” interpretował Wacław Makowski jako „każde działanie, któreby spokój i porządek publiczny naruszało"7. Podkreślał jednocześnie SN, że „ze względu na znaczenie pojęcia "spokój publiczny", można i trzeba rozszerzyć ramy "wybryku« i na czyny, powodujące dotkliwe przeżycia psychiczne" gruncie § 360 pkt 11 niemieckiego kodeksu karnego (dalej - n.k.k.), o brzmieniu: „Kto niewłaściwie wszczyna hałas, zakłócający spokój lub dopuszcza się ciężkiego wybryku”", ujmowano wybryk jako „skierowany wyłącznie przeciwko zewnętrznemu porządkowi publicznemu, zahacza on przeto ogólną obyczajność powszechną (Verkehrssitte), będąca regulatorem stosunków między ludźmi pod względem zewnętrznym i zapewniającą ich trwałość" ${ }^{10}$.

\section{WYKLADNIA ART. 28 PRAWA O WYKROCZENIACH Z 1932 ROKU}

Artykuł 28 Prawa o wykroczeniach z 1932 r. przyją brzmienie: „Kto krzykiem, hałasem, alarmem lub innym wybrykiem zakłóca spokój publiczny, podlega karze [...]”. Podlegający ochronie spokój publiczny zdefiniował SN w wyroku z 20 lipca 1933 r. jako „taki stan rzeczy, który w danem miejscu, porze i czasie, zgodnie z obowiąującemi przepisami prawnemi i ogólnie przyjętemi zwyczajami, uważa się za normalny i którego utrzymanie leży w interesie publicznym. Naruszenie spokoju publicznego polega na spowodowaniu wśród publiczności zaniepokojenia w postaci zatrwożenia, bądź innego wyprowadzenia z równowagi psychicznej jak np. wywołanie uczucia złości, podniecenia, oburzenia, niesmaku itd." ${ }^{11}$. W innym zaś judykacie wyjaśniał, iż spokój publiczny „wyraża pewien nastrój publiczny, istniejący w pewnym momencie i mogący być wypływem najróżnorodniejszych przyczyn, począwszy od górnego odczuwania jak najbardziej wzniosłych zdarzeń, aż do poziomego zadowolenia z istniejącego porządku publicznego" ${ }^{12}$.

na ten temat również Falandysz (1974) oraz SA w Toruniu w wyroku z 21 stycznia 1925 r., T. 292/24, OSP 1926, t. 5, poz. 435.

${ }^{6}$ Wyrok SN z 11 lutego 1924 r., II. K. 47771923 r., Zb. Orz. SN, Orzeczenia Izby Karnej 1924, poz. 32; por. podobnie Makowski (1921): 320.

${ }^{7}$ Makowski (1921): 321 (pisownia oryg.).

${ }^{8}$ Wyrok SN z 11 lutego 1924 r., II. K. 47771923 r.

9 Tłum. Leżański (1930): 286; w wyroku SA w Toruniu z 21 stycznia 1925 r., T. 292/24, OSP 1926, t. 5: „zdrożnej swawoli”, „rażącej niewłaściwości”.

${ }^{10}$ Leżański (1930): 268.

${ }_{11}$ 2K. 478/33, Zb. Orz. SN, Orzeczenia Izby Karnej 1933, poz. 183; por. podobnie wyrok SN z 29 października 1934 r., 1 K. 782/34, Zb. Orz. SN, Orzeczenia Izby Karnej 1935, poz. 190; wyrok SN z 14 września 1936 r., 3 K. 1046/36, Zb. Orz. SN, Orzeczenia Izby Karnej 1937, poz. 49. Pierwotnie natomiast SN w wyrokach: z 27 stycznia 1931 r., II. 4K. 12/31, Zb. Orz. SN, Orzeczenia Izby Karnej 1931, poz. 248; z 2 czerwca 1931 r., II. 4K. 328/31, Zb. Orz. SN, Orzeczenia Izby Karnej 1931, poz. 345.

${ }^{12}$ Wyrok SN z 13 lipca 1933 r., 2K. 460/33. 
Za wybryk uznawano „lekceważenie otoczenia, stawiane własnych fantazyj ponad względy na innych" ${ }^{13}$. Podobnie SN w wyroku z 3 września $1934 \mathrm{r}$. stwierdzał, że „wybrykiem w rozumieniu art. 28 Prawa o wykroczeniach jest takie zachowanie się, jakiego wśród danych okoliczności czasu, miejsca, otoczenia i t. p., ze względu na zwykłe normy ludzkiego współżycia nie należało się spodziewać” ${ }^{14}$. W wyroku z 21 listopada 1933 r. przyjął zaś, że „błędne jest również zapatrywanie, jakoby zakłócenie spokoju dotyczyć mogło jedynie stosunków zewnętrznych poszczególnych osób, a nie ich uczuć wewnętrznych" ${ }^{15}$. Najszerzej ujmował pojęcie wybryku Leon Peiper, przyjmując: „słowy temi [,lub innym wybrykiem” - J.K.], jako klauzula generalna, objęto wszelkie możliwe rodzaje i sposoby zakłócenia spokoju publicznego" ${ }^{16}$. Konweniowało $\mathrm{z}$ takim podejściem zdanie $\mathrm{SN}^{17}$ wyrażone $\mathrm{w}$ innym jeszcze judykacie, zgodnie z którym chodziło generalnie o wykroczenie poza ramy normalnego, powszechnie przyjętego zachowania się, obrazę poczucia zewnętrznego ładu we współżyciu ludzi.

Odnośnie do prac nad obowiązującym Kodeksem wykroczeń należy jedynie zauważyć, że w ich trakcie włączono w zakres karalności art. 51 zakres art. 30 Prawa o wykroczeniach z 1932 r.: „Kto przez uporczywe wybryki zakłóca spoczynek nocny [...]" oraz art. 27 ustawy z 10 grudnia 1959 r. o zwalczaniu alkoholizmu ${ }^{18}$ : „Kto w stanie nietrzeźwości zakłóca porządek publiczny albo wywołuje zgorszenie w miejscu publicznym lub zakładzie pracy [...]”.

\section{WYKŁADNIA ART. 51 § 1 K.W.}

\section{Spokój i porządek publiczny}

Artykuł 51 k.w. chroni prawo jednostki do niezakłóconego wybrykami spokoju i porządku publicznego oraz spoczynku nocnego ${ }^{19}$. Jednakże zdaniem Danuty Egierskiej spokój i porządek publiczny na gruncie art. 51 k.w. mają węższe znaczenia, aniżeli ogólny rodzajowy przedmiot ochrony rozdziału VIII k.w., odnosząc się do konkretnego układu stosunków, konkretnej sytuacji ${ }^{20}$. Definiuje ona spokój publiczny za wyrokiem SN z 29 października 1934 r. jako taki stan rzeczy, który w danym miejscu, porze i czasie, zgodnie z obowiązującymi przepisami prawnymi i ogólnie przyjętymi zwyczajami uważa się za normalny

13 Makarewicz (1938): 680.

14 Wyrok SN z 3 września 1934 r., 2 K. 817/34, Zb. Orz. SN, Orzeczenia Izby Karnej 1935, poz. 79; por. podobnie wyrok SN z 29 maja 1934 r., 3 K. 76/34, Zb. Orz. SN, Orzeczenia Izby Karnej 1935, poz. 8 .

153 K. 952/33, Zb. Orz. SN, Orzeczenia Izby Karnej 1934, poz. 29.

16 Peiper (1936): 649.

17 Wyrok SN z 29 maja 1934 r., 3 K. 76/34; por. podobnie wyrok SN z 3 września 1934 r., 2 K. $817 / 34$.

18 Dz. U. 1959, Nr 69, poz. 434.

19 Tak również Egierska (1970): 16; (1980): 130.

20 Egierska (1970): 18. 
i którego utrzymanie leży w interesie publicznym ${ }^{21}$. Spokój publiczny oznacza stan równowagi psychicznej, brak oznak zdenerwowania, niepokoju większej, nieokreślonej liczby osób ${ }^{22}$. Zakłócenie to wywołanie niepokoju, zamieszania, naruszenie lub zburzenie ustalonego porządku, normalnego biegu spraw ${ }^{23}$. Zakłóceniem spokoju publicznego jest zatem, z kolei za wyrokiem SN z 20 lipca 1933 r. ${ }^{24}$, spowodowanie wśród publiczności zaniepokojenia w postaci zatrwożenia bądź innego wyprowadzenia z równowagi psychicznej, jak np. wywołania uczucia złości, podniecenia, oburzenia, niesmaku itp. ${ }^{25}$ Odmiennie pojmuje to znamię Magdalena Budyn-Kulik. Jej zdaniem chodzi o stan, w którym społeczne (publiczne) funkcjonowanie jednostki nie jest zakłócane przez niepożądane czynniki, o wolność od konieczności ich znoszenia. Publiczność spokoju przejawia się zaś w braku zagrożenia dobrostanu nieokreślonej liczby osób, równowadze funkcjonowania społeczeństwa ${ }^{26}$. Podkreśla Arnold Gubiński, że „zakłócenie równowagi może nastapić przez każde zachowanie się wywołujące zaniepokojenie" ${ }^{27}$.

Już w tym miejscu można stwierdzić, że prezentowanie w takich miejscach, jak: chodniki, place, parkingi, ulice, okolice cmentarza, przydrożne billboardy barwnych, często wielkoformatowych zdjęć zakrwawionych, rozczłonkowanych, martwych ludzkich płodów narusza spokój publiczny. Nie jest zwyczajowo przyjęte ani nie jest uznawane w Polsce za normalne prezentowanie w tego rodzaju przestrzeniach publicznych barwnych zdjęć nagich, zakrwawionych, porozrywanych ludzkich zwłok. Jednostka w swym społecznym, publicznym funkcjonowaniu korzysta z wolności od konieczności znoszenia niepożądanych czynników zakłócajacych uogólniony do uniwersalnego dobra prawnego spokój publiczny ${ }^{28}$. Wychodząc z domu, nie natrafiamy na tego rodzaju obrazy, nie dziwi zatem, że skonfrontowanie z nimi w przypadku natknięcia się na pikietę czy instalację działaczy pro-life burzy ustalony porządek, prowadzi do wyprowadzenia z równowagi psychicznej i powoduje reakcje oburzenia czy niesmaku skutkujące żądaniem ścigania karnego.

Porządek publiczny definiuje Egierska za wyrokiem SN z 11 lutego 1924 r. jako uregulowany według pewnych zasad wzajemny stosunek zewnętrzny lu-

21 Egierska (1970): 19.

22 Falandysz (1974): 16-17, 41, 44; por. podobnie Kasicki, Wiśniewski (2002): 188; Bojarski (2012): 135, 140; Bojarski (2019): teza 21; (1992): 42; Kurzępa (2008): teza 7; Sawicki (1997): 101, 102; (2000): 231.

${ }^{23}$ Egierska (1980): 131; por. podobnie: Kurzępa (2008): teza 6; Kozłowska-Kalisz (2009): teza 5; Jankowski (2013a): teza 3; Budyn-Kulik (2019): 328.

${ }^{24}$ 2K. 478/33; podobnie w wyrokach SN: z 13 lipca 1933 r., 2K. 460/33, Zb. Orz. SN, Orzeczenia Izby Karnej, 1933, poz. 181; z 29 września 1936 r., 3 K. 1178/36, Zb. Orz. SN, Orzeczenia Izby Karnej 1937, poz. 72; z 29 października 1934 r.,1 K. 782/34.

${ }_{25}$ Egierska (1970): 19; por. podobnie: Marek (2008): 117, 120; Radecki (1986): 65; wyrok SN z 2 grudnia 1992 r., III KRN 189/92, Lex nr 162227, i wszyscy powołani dalej autorzy, przytaczający aprobująco ten judykat.

${ }^{26}$ Budyn-Kulik (2019): 328.

27 Gubiński (1985): 258; por. podobnie Kasicki, Wiśniewski (2002): 188.

${ }^{28}$ Odnośnie do tego, co jednostka musi znosić w ramach konfrontacji z nieskrępowaną debata publiczna, por. na gruncie orzecznictwa ETPC: Kulesza (2020c). 
dzi lub rzeczy ${ }^{29}$. Rozwija następnie tę definicję, nawiązując wyraźnie do wyroków SN z 20 lipca 1933 r. i z 29 października 1934 r., by przyjąć, że porządkiem publicznym jest zachowanie się ludzi w miejscach publicznych, które jest zgodne z ogólnie przyjętymi normami społecznymi i którego utrzymanie leży w interesie społecznym ${ }^{30}$. Jest to zatem ,społeczny ład, życie zgodne z prawem i obyczajami panującymi w danym społeczeństwie”31. Zakłóceniem tak pojmowanego porządku publicznego jest naruszenie owego normalnego, wolnego od zakłóceń biegu życia zbiorowego ${ }^{32}$. W sposób bardziej syntetyczny ujmuje definicję pojęcia porządku publicznego Andrzej Marek, przyjmując, że chodzi o „uporządkowany odpowiednimi przepisami, wolny od zakłóceń bieg życia zbiorowego" 33 .

Również z punktu widzenia znamienia porządku publicznego można przyjąć, że prezentowanie wspomnianych zdjęć prowadzi do naruszenia owego porządku. Oceniane zachowania działaczy pro-life stoją w sprzeczności z powszechnie przyjmowanymi w Polsce normami społecznymi zachowań publicznych. Normy te nie dopuszczają narzucania publicznie odbioru obrazów zakrwawionych ludzkich szczątków.

Michał Kulczycki i Jerzy Zduńczyk definiują spokój i porządek publiczny łącznie jako „taki stan faktyczny i prawny, który w danym miejscu i czasie zgodnie z obowiązującymi przepisami, zasadami współżycia społecznego i ogólnie przyjętymi zwyczajami, jest uważany za normalny i odpowiadający odczuciom ogółu obywateli i którego utrzymanie z tego względu leży w interesie publicznym"34. Podobnie Tadeusz Bojarski ujmuje oba przedmioty ochrony łącznie, stwierdzając, że „chodzi o takie zachowania jednego człowieka lub grupy osób, które nie zakłócają spokoju innych ludzi lub porządku publicznego opierającego się na pewnej stabilności reguł funkcjonujących w danym środowisku" 35 .

Jak zauważa Egierska, choć na ogół zakłócenie spokoju pociaga za soba zakłócenie porządku publicznego, zakłócenie porządku zaś z reguły narusza spokój publiczny, to jednak pojęcia te nie są tożsame ${ }^{36}$. Zdaniem Lecha Falandysza zakłócenie porządku publicznego następuje w przypadku utrudnienia lub uniemożliwienia innym ludziom normalnego zachowania $\mathrm{w}$ miejscach publicznych, skutek ten musi zaś odczuć choćby jedna osoba ${ }^{37}$. Natomiast zakłócenie spokoju publicznego następuje w przypadku naruszenia równowagi psy-

\footnotetext{
29 Egierska (1970): 20.

30 Egierska (1980): 131; por. podobnie Bojarski (2012): 135; Kurzępa (2008): teza 7; Krajewski (2010): 119.

31 Kasicki, Wiśniewski (2002): 188; por. podobnie Budyn-Kulik (2019): 302.

32 Gubiński (1985): 258, 264; por. podobnie: Marek (2008): 120; Bojarski (2015): teza 3; Jankowski (2013a): teza 3; Sawicki (1997): 101; (2000): 231; Budyn-Kulik (2019): 328.

${ }^{33}$ Marek (2008): 117; por. podobnie Bojarski (2012): 135, 140.

${ }^{34}$ Kulczycki, Zduńczyk (1982): 74; (1972): 87; por. podobnie Kotowski (2009): teza 1.

35 Bojarski (2012): 140.

36 Egierska (1970): 20-21; (1980): 131; por. podobnie: Gubiński 1985): 264; Bojarski (2012): 140; Sawicki (1997): 104, 105.

37 Falandysz (1974): 56-57; (1969): 69; por. podobnie Egierska (1980): 131; Bojarski (2019): teza 23; (1992): 43; Radecki (1984): 53; (1986): 65; Kurzępa (2008): teza 7; Kotowski (2009): teza 2;
} 
chicznej grup lub jednostek znajdujących się w miejscu publicznym ${ }^{38}$. Również w tym przypadku wystarczające jest zakłócenie równowagi psychicznej choćby jednej osoby znajdującej się w miejscu publicznym ${ }^{39}$.

Odnosząc te zasady do omawianej działalności pro-life, należy przyjaćc, że wystarczające jest stwierdzenie naruszenia spokoju publicznego lub porządku publicznego po stronie jednej choćby osoby, by otwarła się możliwość postawienia zarzutu z art. $51 \S 1 \mathrm{k}$.w., co nie neguje materialnego charakteru omawianego wykroczenia, o którym będzie mowa w części dalszej.

Należy na marginesie zauważyć, że przedstawiona przez SN w wyroku z 2 grudnia 1992 r. $^{40}$ i powoływana aprobująco w doktrynie ${ }^{41}$ definicja zakłócenia porządku publicznego jako wywołania „stanu, który w danym miejscu, czasie i okolicznościach, zgodnie z przyjętymi zwyczajami i obowiązującymi przepisami, uważa się za nienormalny i który, w obiektywnym odbiorze, odczuwany jest jako utrudnienie lub uniemożliwienie powszechnie akceptowanego sposobu zachowania się w miejscach dostępnych dla bliżej nieokreślonej liczby osób” nawiązuje z jednej strony do definicji zakłócenia porządku publicznego Falandysza, z drugiej zaś - do definicji SN z wyroku z 29 października 1934 r. Jednak definicja $\mathrm{z}$ tego wyroku dotyczyła pojęcia spokoju publicznego, a nie porządku publicznego. Osobno natomiast definiuje SN w wyroku z 1992 r. zakłócenie spokoju publicznego właśnie.

\section{Zgorszenie w miejscu publicznym}

Zgorszenie w miejscu publicznym określa Egierska jako wywołanie swoim zachowaniem negatywnej, potępiającej reakcji otoczenia ${ }^{42}$, takiej jak wstręt, obrzydzenie, oburzenie, niesmak ${ }^{43}$. Zdaniem Gubińskiego zgorszenie jest rodzajem naruszenia stanu równowagi psychicznej, a ustawodawca wyodrębnił ten rodzaj prawnokarnie relewantnego skutku, by wyeksponować taki przedmiot ochrony, zwrócić nań uwage stosujących prawo ${ }^{44}$. Kulczycki i Zduńczyk przyjmują z kolei, że wywołanie zgorszenia „to działanie, polegające na naruszeniu przyjętych w społeczeństwie norm postępowania i zachowania, ma-

Kozłowska-Kalisz (2009): teza 5; Jankowski (2013a): teza 3; Sawicki (1997): 101; (2000): 231; Krajewski (2010): 119.

${ }^{38}$ Falandysz (1974): 44; (1969): 69; por. podobnie Egierska (1980): 131; Radecki (1984): 53; Bojarski (2015): teza 3.

${ }^{39}$ Egierska (1980): 131; por. podobnie Bojarski (2019): teza 21; (1992): 42; Radecki (1984): 53; (1986): 65; Kozłowska-Kalisz 2009): teza 5; Bojarski (2015): teza 3; Jankowski (2013a): teza 3; Sawicki (1997): 102; Krajewski (2010): 119.

${ }^{40}$ Wyrok SN z 2 grudnia 1992 r., III KRN 189/92, Lex nr 162227.

${ }^{41}$ Bojarski (2019): tezy 11, 24; Jankowski (2013b): 78; (2013a): tezy 2, 3; Kurzępa (2008): teza 6; Kotowski (2009): teza 7; Kozłowska-Kalisz (2009): teza 7; Bojarski (2015) teza 3; Krajewski (2010): 117; Budyn-Kulik (2019): 328.

${ }^{42}$ Egierska (1970): 21; (1980): 132; por. podobnie Falandysz (1974): 78; Kasicki, Wiśniewski (2002): 189; Kurzępa (2008): teza 9.

${ }^{43}$ Bojarski (2019): teza 28; (1992): 45; por. podobnie: Radecki (1984): 53; (1986): 66; Kozłowska-Kalisz (2009): teza 6; Krajewski (2010): 120; Budyn-Kulik (2019): 331.

${ }^{44}$ Gubiński (1985): 263-264. 
jących na celu zabezpieczenie poczucia przyzwoitości i dobrych obyczajów"45. Niekiedy uzupełnia się zatem w związku ze znamieniem „zgorszenia” katalog chronionych przez art. $51 \mathrm{k}$.w. dóbr również o obyczajność publiczna ${ }^{46}$. Znajduje to uzasadnienie również w wykładni historycznej, skoro § 360 pkt 11 n.k.k. chronił „ogólną obyczajność powszechną (Verkehrssitte), będącą regulatorem stosunków między ludźmi”" ${ }^{47}$.

Jak podkreśla Egierska, sąd powinien ocenić realizację tego znamienia biorąc pod uwagę towarzyszące czynowi okoliczności, takie jak miejsce i czas czynu czy osoby będące świadkami wybryku i ich reakcję ${ }^{48}$. Wywołanie zgorszenia może wynikać z naruszenia obyczajności publicznej. Możliwe jest kwalifikowanie zachowań działaczy pro-life również jako prowadzących do publicznego zgorszenia, skoro podstawową kwalifikacją ich zachowań jest art. 140 k.w. chroniący właśnie publiczną obyczajność ${ }^{49}$.

\section{Materialny charakter wykroczenia}

Zdaniem Egierskiej zarówno wybryk zakłócający spokój lub porządek publiczny, jak i wybryk wywołujący zgorszenie muszą pociagać za sobą nastapienie skutku w postaci zakłócenia spokoju lub porządku publicznego albo wywołania zgorszenia ${ }^{50}$. Nie wystarczy stwierdzenie jedynie możliwości zakłócenia spokoju publicznego, spokój ten musi zostać rzeczywiście zakłócony, przy czym wystarczające jest zakłócenie spokoju (równowagi psychicznej) czy porządku publicznego choćby jednej osoby ${ }^{51}$, jak już wcześniej wykazano. Jak wyjaśnia Gubiński, ze stwierdzonego naruszenia spokoju lub porządku publicznego choćby jednej osoby można wywnioskować, że skutek taki dotyczy większej ilości osób, które znajdowały się w analogicznej czy bliskiej do niej sytuacji jako odbiorcy wybryku. Wybryk musi być zatem popełniony w sytuacji i okolicznościach, w których mógł był dotrzeć do więcej niż jednej osoby ${ }^{52}$. Jednakże zdaniem Marka Bojarskiego trudno nie przyjąc realizacji znamion wykroczenia również i wtedy, gdy ustali się jednego tylko bezpośrednio pokrzywdzonego inkryminowanym zachowaniem i nie ustali, że skutek ów mógł dotknąć jeszcze inne osoby. W razie zatem stwierdzenia skutku po stronie jednej tylko

\footnotetext{
${ }^{45}$ Kulczycki, Zduńczyk (1982): 75; (1972): 88.

${ }^{46}$ Kasicki, Wiśniewski (2002): 188; por. podobnie Budyn-Kulik (2019): 327, 330.

${ }^{47}$ Wyrok SN z 27 stycznia 1931 r., II. 4K. 12/31; por. podobnie wyrok SN z 2 czerwca 1931 r., II. 4 K. $328 / 31$.

${ }^{48}$ Egierska (1970): 21; (1980): 132; por. podobnie Jankowski (2013a): teza 5.

${ }_{49} \mathrm{Na}$ temat prawidłowej wykładni dobra chronionego w postaci obyczajności publicznej oraz jego odniesienia do publicznej moralności i porządku publicznego oraz odpowiedzialności karnej sensu largo działaczy pro-life por. pozycje przytoczone w przyp. 3.

${ }^{50}$ Egierska (1970): 17, 22; (1980): 131; por. podobnie Gubiński (1985): 263; Marek (2008): 120; Kasicki, Wiśniewski (2002): 188.

${ }^{51}$ Egierska (1970): 19, za wyrokiem SN z 13 lipca 1933 r., 2K. 460/33; (1980): 131, 132; por. podobnie Kasicki, Wiśniewski (2002): 188.

${ }^{52}$ Gubiński (1985): 264; por. podobnie: Kulczycki, Zduńczyk (1982): 74; Bojarski (2019): teza 24; (1992): 42, 43; Radecki (1986): 65.
} 
osoby również następuje dokonanie czynu z art. $51 \S 1 \mathrm{k} . \mathrm{w} .{ }^{53}$ Odmiennie natomiast pojmuje materialny charakter omawianego wykroczenia Budyn-Kulik, przyjmując, że skutkiem jest obiektywne zakłócenie spokoju i porządku publicznego, nawet bez stwierdzenia bezpośrednio tego skutku po stronie choćby jednej osoby ${ }^{54}$.

Także odnośnie do zgorszenia przyjmuje się, że wystarczy jego stwierdzenie u jednej choćby osoby znajdującej się w miejscu publicznym ${ }^{55}$, o przeciętnej (nie nadmiernej) wrażliwości ${ }^{56}$. W tym przypadku jednak, ponieważ zgorszenie nie musi mieć charakteru publicznego, nie domniemywa się ani nie dowodzi z okoliczności czynu zaistnienia zgorszenia większej, nieoznaczonej liczby osób. Fakt, że została zgorszona jedna osoba, zawsze wyczerpuje znamiona wykroczenia ${ }^{57}$.

Odnosząc te zasady do omawianego zagadnienia, należy przyjąć rozwiązanie następujące. Przede wszystkim konieczne jest rozróżnienie między odpowiedzialnością z art. 140 i 141 a 51 § 1 k.w. Pomocna jest tu wykładnia dokonana przez Egierską-Miłoszewską w stosunku do oceny załatwiania potrzeby fizjologicznej na ulicy. Jak pisze ta autorka, zachowanie takie na ulicy, nawet w obecności przechodniów, którzy jednak nie reagowali, stanowi czyn z art. 140 k.w. Jeśli jednak czyn sprawcy wywołał zgorszenie przechodniów, co wyrażało się w wypowiadanych przez nich głośno uwagach, czyn taki należy kwalifikować z art. $51 \mathrm{k} . w .{ }^{58}$ Tak samo w przypadku prezentowania omawianych zdjęć płodów brak reakcji przechodniów pozwala na postawienie zarzutu jedynie z art. 140 k.w. (czy art. 141 k.w.), jeśli natomiast zaistniał skutek w postaci naruszenia spokoju lub porządku publicznego albo zgorszenia u choćby jednej osoby, należy sięgnąć po art. $51 \mathrm{k}$.w. Wymaga podkreślenia, że brak stwierdzenia zaistnienia skutku po stronie jednej nawet osoby nie znosi odpowiedzialności karnej sensu largo, lecz pozostawia kwalifikację prawną na gruncie art. 140 k.w. albo 141 k.w., statuujących formalne typy wykroczeń. Natomiast przechodząc na grunt art. $51 \S 1 \mathrm{k} . \mathrm{w}$. i biorąc pod uwage towarzyszące czynowi okoliczności, takie jak miejsce i czas czynu czy osoby będace świadkami wybryku działaczy pro-life i ich reakcję, należy wskazać zaistniały skutek jako zakłócenie spokoju publicznego, zakłócenie porządku publicznego bądź wywołanie zgorszenia, skoro skutki te muszą podlegać różnicowaniu (zostały przecież przez ustawodawce wyodrębnione). Wydaje się, że w zależności od natężenia reakcji publiczności i stopnia naruszenia normalnego, wolnego od zakłóceń biegu życia zbiorowego należy przyjmować w kolejności: zakłócenie spokoju publicznego, wywołanie zgorszenia, a wreszcie zakłócenie porząd-

53 Bojarski (1992): 43, 44; por. podobnie Sawicki (1997): 101.

54 Budyn-Kulik (2019): 330-331.

55 Egierska (1980): 132; por. podobnie Kasicki, Wiśniewski (2002): 189; Bojarski (2019): teza 28; (1992): 45; Radecki (1984): 53; (1986): 66; Kurzępa (2008): teza 9; Kozłowska-Kalisz (2009): teza 6; Jankowski (2013): teza 5.

${ }^{56}$ Radecki (1984): 53; (1986): 66; Krajewski (2010): 120; Budyn-Kulik (2019): 330, 331.

${ }^{57}$ Gubiński (1985): 265.

58 Egierska-Miłoszewska (1979): 70. 
ku publicznego. Wywołanie zgorszenia ${ }^{59}$ jawi się jako reakcja silniejsza aniżeli zakłócenie spokoju publicznego, od niego z kolei dalej idące wydaje się zakłócenie aż porządku publicznego. Jednakże z punktu widzenia procesowego najprostsze do przypisania jest wywołanie zgorszenia, skoro wystarczy zgorszenie jednej osoby w miejscu publicznym, bez konieczności wywnioskowania, że skutek taki dotyczył większej ilości osób, które znajdowały się w analogicznej czy bliskiej do dotkniętej osoby sytuacji jako odbiorcy wybryku. Przy czym, biorąc pod uwagę sposób i miejsca omawianej aktywności działaczy pro-life (place, chodniki, parkingi, billboardy itd.), również wykazanie, że stwierdzony już skutek dotyczył także innych osób znajdujących się w analogicznej czy bliskiej sytuacji, nie powinno nastręczać trudności.

\section{Pojęcie wybryku}

Pojęcie wybryku definiuje się, przyjmując frazę z wyroku SN z 3 września 1934 r., według której wybrykiem jest takie zachowanie się, jakiego wśród danych okoliczności czasu, miejsca, otoczenia itp., ze względu na zwykłe normy ludzkiego współżycia, nie należało się spodziewaćco ${ }^{60}$ a które zdolne jest zakłócić spokój lub porządek publiczny ${ }^{61}$. W nowszym o niemal 60 lat judykacie $^{62}$ zmienia nieco SN zdanie, uzupełniając pierwszą część przytoczonej definicji o „wywołanie powszechnie negatywnych ocen społecznych i uczucia odrazy, gniewu, oburzenia” oraz stwierdzenie, zgodnie z którym „wybryk charakteryzuje więc ostra sprzeczność z powszechnie akceptowanymi normami zachowania się". Jeszcze węższą definicję przyjmuje Gubiński, twierdząc, że „wybrykiem jest zachowanie się rażąco odbiegające od przyjętego w danych warunkach i okolicznościach, które spotyka się z ujemną oceną społeczną", zachowanie „pozostające w ostrej sprzeczności z zasadami współżycia społecznego" ${ }^{3}$. W podobny sposób ujmuje to Falandysz, przyjmując definicję, zgodnie z którą wybrykiem jest czyn rażąco odbiegający od przyjętych w danych okolicznościach obowiązujących norm zachowania się i okazujący lekceważenie ich przez sprawcę (czyn poważnie kolidujący z obowiązującymi w danej sytuacji normami zachowania się, które sprawca lekceważy) ${ }^{64}$. W doktrynie przyjmuje się jednak również i pierwotne, szersze rozumienie pojęcia wybryku. Przykładowo Kulczycki i Zduńczyk uznaja, że wybrykiem jest „działanie, któ-

${ }^{59} \mathrm{Na}$ jego temat w omawianym kontekście por. pozycje z przyp. 3.

${ }^{60}$ Egierska (1970): 18; por. podobnie SN w wyroku z 2 grudnia 1992 r., III KRN 189/92, Lex nr 162227, i wszyscy powołani wcześniej autorzy, przytaczający aprobująco ten judykat.

${ }^{61}$ Egierska (1980): 130; por. podobnie Jankowski (2013b): 77.

${ }^{62}$ Wyrok SN z 2 grudnia 1992 r., III KRN 189/92, Lex nr 162227; por. podobnie Bojarski (2019): teza 16; Kurzępa (2008): teza 4; Kotowski (2009): teza 7; Bojarski (2015): teza 3.

${ }^{63}$ Gubiński (1985): 263; por. podobnie: Marek (2008): 120; Bojarski (2019): teza 4; (1992): 40; Radecki (1986): 65; Sawicki (1997): 108.

${ }^{64}$ Falandysz (1974): 30; por. podobnie Bojarski (2019): teza 7; (1992): 40-41; Kozłowska-Kalisz (2009): teza 2; Krajewski (2010): 117; Budyn-Kulik (2019): 331; wyrok SN z 30 stycznia 2018 r., IV KK 475/17, OSP 2018, nr 12, poz. 124. 
re, odbiegając od przyjętych zwyczajowo norm zachowania się[${ }^{65}$ - przyp. J.K.], narusza lub zagraża naruszeniem spokoju i porządku publicznego i przez to zdolne jest do wywołania niepokoju, oburzenia, gniewu oraz innych tego typu zjawisk godzących w równowagę psychiczną człowieka"66. Najszerzej ujmuje pojęcie wybryku Paweł Petasz, stwierdzając, że „wybrykiem zatem w rzeczywistości może być każde zachowanie człowieka, które negatywnie odbiega od przyjętych norm ludzkiego postępowania w określonych okolicznościach”, które „nie powinno wystapic”"67.

Przyłączając się do wyrażonego ostatnio poglądu Pawła Daniluka ${ }^{68}$, należy odrzucić te z powyższych wykładni, które bezpodstawnie zawężają zakres pojęcia wybryku. Wykładnia językowa, historyczna, historyczna celowościowa, prawnoporównawcza i systemowa wskazuja, że pojęcie wybryku musi być interpretowane szeroko - jako zachowanie, jakiego wśród danych okoliczności czasu, miejsca, otoczenia itp., ze względu na zwykłe normy ludzkiego współżycia, nie należało się spodziewać. Żaden ze wspomnianych rodzajów wykładni nie daje podstaw do ograniczania wybryku jedynie do „ostrej sprzeczności” czy „rażącego" naruszenia norm zachowania się oraz wtłaczania w definicję samej czynności sprawczej w postaci wybryku jego skutków: „wywołania powszechnie negatywnych ocen społecznych i uczucia odrazy, gniewu, oburzenia”. Te ujęte sa w odrębnych znamionach, zawartych w art. $51 \S 1$ k.w. Stanowiący jeden z pierwowzorów obecnego rozwiązania $\S 360$ ust. 11 n.k.k. posługiwał się pojęciem „ciężkiego wybryku”, którego ustawodawca nie recypował do art. 28 Prawa o wykroczeniach z 1932 r., wprowadzając jedynie znamię „wybryku”. Stosując założenie racjonalności ustawodawcy, należy przyjąć, że uczynił to celowo, skłaniając się w większym stopniu do zakresu karalności art. 262 r.k.k. ${ }^{69} \mathrm{~W}$ związku z tym i pierwotna, trafna, wykładnia doktryny i judykatury przyjmowała szerokie rozumienie tego pojęcia. Słusznie wskazuje wreszcie Daniluk, że ilekroć ustawodawca chce ograniczyć zakres karalności, posługuje się znamionami takimi, jak „rażące lekceważenie” (art. $47 \S 5$ k.w.) czy „rażące naruszenie” (art. $105 \S 1,138 \mathrm{c} \S 1 \mathrm{k} . w.)^{70}$. W art. $51 \S 1$ takiego znamienia brak, w związku z czym nie można dokonywać wykładni, uzupełniając treść tego wykroczenia o nieistniejące znamię.

Niezależnie od tego, czy aprobując powyższe uwagi, przyjmie się trafna, pierwotna, szeroką wykładnię pojęcia wybryku, czy wykładnię w sposób nieuprawniony zawężoną - omawiane inkryminowane sensu largo zachowania działaczy pro-life realizują każdą z definicji wybryku. Biorąc pod uwagę, że na ulicach, placach, parkingach, billboardach w Polsce nie eksponuje się obrazów, w szczególności wielkoformatowych, nagich, porozrywanych, zakrwawionych

65 Kasicki, Wiśniewski (2002): 189; por. podobnie Kurzępa (2008): teza 3; Bojarski (2015): teza 3; Daniluk (2019): 51.

${ }^{66}$ Kulczycki, Zduńczyk (1982): 74; (1972): 87; por. podobnie Bojarski (2012): 140; Jankowski (2013b): 77; (2013a): teza 1; Kozłowska-Kalisz (2009): teza 2; Krajewski (2010): 118.

${ }^{67}$ Petasz (2018): 94, 95.

68 Daniluk (2019): 52.

69 Tak przyjmuje również Falandysz (1974): 27.

70 Daniluk (2019): 53. 
ludzkich zwłok, umieszczenie takich treści w tych miejscach pozostaje w ostrej sprzeczności z powszechnie akceptowanymi normami zachowania się, rażąco od nich odbiegajacc ${ }^{71}$. Przy czym dowodzenie tego nie jest wcale konieczne, skoro prawidłowa wyładnia pojęcia wybryku (jako zachowania, którego w danych okolicznościach czasu, miejsca, otoczenia itp., ze względu na zwykłe normy ludzkiego współżycia nie należało się spodziewać) już przesądza o przedstawionej ocenie posługiwania się inkryminowanymi zdjęciami. Czy należy się bowiem spodziewać, wychodząc z domu i udając w miejsca publiczne, jak: plac, chodnik, parking, czy obserwując przydrożne billboardy, że zostanie się skonfrontowanym z drastycznymi, barwnymi zdjęciami nagich, rozczłonkowanych, zakrwawionych ludzkich zwłok?

\section{Strona podmiotowa wykroczenia}

Jak przyjmuje Egierska, wykroczenie z art. $51 \S 1$ k.w. może być popełnione zarówno umyślnie, jak i nieumyślnie. Realizacja znamion następuje również wówczas, gdy zachowanie sprawcy ujęte w zespole znamion objęte jest umyślnością (np. słucha w porze nocnej głośno muzyki), lecz nie ma on zamiaru sprowadzenia skutku (nie chce obudzić sasiadów, zakładając, że muzyka nie jest aż tak głośna bądź ściany wytłumią hałas ${ }^{72}$. Umyślność cechuje zawsze jedynie wybryk, jego skutki mogą być objęte również nieumyślnością ${ }^{73}$. Odmiennego, odosobnionego na tle doktryny i judykatury, zdania jest Patrycja Kozłowska-Kalisz, która uważa, że w grę może wchodzić jedynie umyślne dopuszczenie się omawianego czynu ${ }^{74}$. Na krańcowo odmiennym stanowisku stoją natomiast Budyn-Kulik i Daniluk, których zdaniem czynu z art. $51 \S 1$ k.w. można dopuścić się również nieumyślnie - obejmując nieumyślnością nie tylko sam skutek, lecz także zachowanie w postaci wybryku ${ }^{75}$. Konweniuje to z podejściem SN zaprezentowanym w wyroku z 29 października 1934 r., gdzie dopuścił on możliwość popełnienia czynu z art. 28 Prawa o wykroczeniach z 1932 r. również z „winy nieumyślnej”.

Wyraźnie podkreśla się $\mathrm{w}$ doktrynie, że strony podmiotowej wybryku w postaci umyślności nie charakteryzuje szczególna pobudka ją zabarwiająca w postaci „swawoli”. Wybryku może się sprawca dopuścić ze swawoli, lecz nie jest to konieczne do przypisania umyślności jego działania ${ }^{76}$. Sąd Najwyższy zawęża jednak zakres strony podmiotowej, przyjmując, że sprawca musi przez wybryk umyślnie okazać lekceważenie dla obowiązujących norm zachowania

71 Polemicznie względem chybionych analogii do ostrzeżeń na opakowaniach papierosów oraz kampanii społecznych por. w pozycjach przytoczonych w przyp. 3.

72 Egierska (1980): 135; por. podobnie Gubiński (1985): 266.

${ }^{73}$ Gubiński (1985): 264; por. podobnie: Falandysz (1974): 113; Marek (2008): 120; Bojarski (2012): 141; Kasicki, Wiśniewski (2002): 188; Jankowski (2013b): 78; (2013a): teza 10; Bojarski (2019): teza 36; (2015): teza 5; Radecki (1986): 66; Sawicki (1997): 109; (2000): 235; pierwotnie natomiast SA w Toruniu w wyroku z 21 stycznia 1925 r., T. 292/24.

${ }^{74}$ Kozłowska-Kalisz (2009): teza 12.

75 Budyn-Kulik (2019): 333-334; Daniluk (2019): 54.

${ }^{76}$ Falandysz (1974): 31; por. podobnie Bojarski (2019): teza 9; (1992): 41. 
się $^{77}$. Trafnie poddaje krytyce taką wykładnię Daniluk, wskazując, że nie ma dla niej żadnych podstaw ${ }^{78}$. Wykładnia językowa, historyczna, historyczna celowościowa, prawnoporównawcza i systemowa sprzeciwiają się wręcz zawężaniu pojęcia wybryku i strony podmiotowej omawianego wykroczenia. Słusznie wskazuje Daniluk, że gdyby ustawodawca chciał zawęzić zakres karalności art. $51 \S 1$ k.w. do zachowań lekceważących normy zachowania się, uczyniłby to wprost, jak w art. $49 \S 1 \mathrm{k} . w$. („demonstracyjnie okazuje lekceważenie”). Wobec braku takiego znamienia na gruncie art. $51 \S 1$ k.w. nie ma podstaw do formułowania tego rodzaju wymogu. Równie trafnie wskazuje również, że przez przyjęcie, że wybryk ma stanowić rażące lekceważenie norm zachowania się, następuje zatarcie różnicy między czynem z art. $51 \S 1 \mathrm{k} . w$. a czynem o charakterze chuligańskim (art. $47 \S 5 \mathrm{k} . w$. - „rażące lekceważenie podstawowych zasad porządku prawnego"), a co za tym idzie, $\S 1$ i $§ 2$ art. 51 k.w. ${ }^{79}$

$\mathrm{W}$ interesującym nas zakresie wystarczające jest wykazanie zamiaru (choćby ewentualnego) zaprezentowania publicznie bądź w miejscu publicznym inkryminowanych zdjęć, przy świadomości, że zwykłe normy ludzkiego współżycia w Polsce nie zezwalają na narzucanie publiczności odbioru tego rodzaju treści. Dla realizacji znamion wykroczenia z art. $51 \S 1$ k.w. nie ma zatem znaczenia ewentualny brak zamiaru po stronie działaczy pro-life naruszenia spokoju lub porządku publicznego lub wywołania zgorszenia. Wystarczające jest przewidywanie albo możliwość przewidywania, że prezentowane przez nich treści wywołają zgorszenie, doprowadzą do naruszenia spokoju lub porządku publicznego. Odnośnie do dekodowania strony podmiotowej czynów działaczy pro-life należy zauważyć, że za przewidywaniem, a nie jedynie możliwością przewidywania nastapienia skutków ujętych w art. $51 \S 1$ k.w. będa przemawiały nie tylko powtarzające się reakcje osób przypadkowo skonfrontowanych z prezentowanymi przez nich treściami, lecz również długa historia toczonych przeciw nim postępowań sądowych w sprawach o naruszenie art. 51, art. 140 czy art. 141 k.w.

\section{PODSUMOWANIE}

Jak to trafnie ują SN w wyroku z 28 sierpnia 1934 r. ${ }^{80}$ : „życie jednak zakreśla swobodzie jednostek pewne granice, ustalając bądź drogą przepisów prawnych, bądź powszechnie uznanych zwyczajów, reguły zachowania się i postępowania, których celem jest sprowadzenie nieuniknionego w życiu zbio-

${ }^{77}$ Wyrok SN z 30 września 2002 r., III KKN 327/02, Lex nr 55571; por. podobnie wyrok SN z 30 stycznia 2018 r., IV KK 475/17; Kurzępa (2008): teza 4; Kozłowska-Kalisz (2009): teza 2; Bojarski (2015): teza 5; Krajewski (2010): 117.

${ }^{78}$ Daniluk (2019): 54.

${ }^{79}$ Daniluk (2019): 54-55.

${ }^{80}$ Wyrok SN z 13 czerwca 1933 r., 2K. 366/33, Zb. Orz. SN, Orzeczenia Izby Karnej 1933, poz. 170; por. podobnie wyrok z SN 10 września 1936 r., 1 K. 434/36, Zb. Orz. SN, Orzeczenia Izby Karnej 1937, poz. 44. 
rowem wzajemnego niepokojenia się do pewnej określonej miary, uwzględniającej z jednej strony interes jednostki, a z drugiej interes ogółu, a których naruszenie uważane jest za uchybienie, zagrażajace stanowi, którego utrzymanie leży w interesie publicznym”. I następnie: „nawet niewinne skądinąd działanie może przybrać cechy wybryku [...], jeśli [...] przedstawiać się będzie jako wyłamanie się z pod przyjętych norm obyczajowości zewnętrznej”81.

Jan Kulesza

Uniwersytet Łódzki

jkulesza@wpia.uni.lodz.pl

https://orcid.org/0000-0002-0574-9120

Bojarski, M. (1992). Problemy kwalifikacji prawnej wykroczeń. Wybrane zagadnienia. Wrocław.

Bojarski, M. (2019). Art. 51 [Zakłócenie porządku], [w:] M. Bojarski, W. Radecki, Kodeks wykroczeń. Komentarz. [Online] Legalis.

Bojarski, T. (2012). Polskie prawo wykroczeń. Zarys wykładu. Warszawa.

Bojarski, T. (2015). Art. 51 [Zakłócenie spokoju lub porządku publicznego], [w:] T. Bojarski (red.), Kodeks wykroczeń. Komentarz. [Online] Lex.

Budyn-Kulik, M. (2019). Art. 51 [Zakłócenie porządku], [w:] P. Daniluk (red.), Kodeks wykroczeń. Komentarz. Warszawa: 327-337.

Daniluk, P. (2019). O wykroczeniu z art. 51 § 1 kodeksu wykroczeń (w związku z wyrokiem SN z 30.01.2018 r., IV KK 475/17). Państwo i Prawo 74(1): 39-58.

Egierska, D. (1970). Artykuł 50 projektu Prawa o wykroczeniach. Zagadnienia Karno-administracyjne 15(3): 15-27.

Egierska, D. (1980). Zakłócenie wybrykiem spokoju lub porządku publicznego, [w:] J. Bafia, D. Egierska, I. Śmietanka, Kodeks wykroczeń. Komentarz. Warszawa: 130-135.

Egierska-Miłoszewska, D. (1979). Nieobyczajny wybryk (art. 140 k.w. w teorii i praktyce). Zagadnienia Wykroczeń 24(4/5): 65-75.

Falandysz, L. (1969). Pojęcie porządku publicznego w prawie karnym i karno-administracyjnym. Palestra 13(2): 63-74.

Falandysz, L. (1974). Wykroczenie zakłócenia porządku publicznego. Warszawa.

Gubiński, A. (1985). Prawo wykroczeń. Warszawa.

Jankowski, W. (2013a). Art. 51 [Zakłócenie spokoju lub porządku publicznego], [w:] T. Grzegorczyk (red.), Kodeks wykroczeń. Komentarz. [Online] Lex.

Jankowski, W.J. (2013b). § 43. Zakłócenie spokoju lub porządku publicznego (art. $51 \mathrm{KW),} \mathrm{[w:]}$ M. Błaszczyk, W.J. Jankowski, M. Zbrojewska, Prawo i postępowanie w sprawach o wykroczenia. Warszawa: 77-78.

Kasicki, G., Wiśniewski, A. (2002). Kodeks wykroczeń z komentarzem. Warszawa.

Kotowski, W. (2009). Art. 51 [Zakłócenie spokoju], [w:] Kodeks wykroczeń. Komentarz. [Online] Lex.

Kozłowska-Kalisz, P. (2009). Art. 51, [w:] M. Mozgawa (red.), Kodeks wykroczeń. Komentarz. [Online] Lex.

Krajewski, R. (2010). Wykroczenia wybryku i nieobyczajnego wybryku. Przegląd Sądowy 19(11/12): 116-128.

Kulczycki, M., Zduńczyk, J. (1972). O nowym kodeksie wykroczeń. Warszawa.

Kulczycki, M., Zduńczyk, J. (1982). Kodeks wykroczeń. Popularny komentarz. Warszawa.

Kulesza, J. (2019a). Glosa do wyroku Sądu Okręgowego w Opolu z dnia 10 grudnia 2018 r., VII Ka 956/18. Studia Iuridica Lublinensia 28(2): 177-191.

Kulesza, J. (2019b). Publiczne prezentowanie zdjęć martwych płodów jako nieobyczajny wybryk (art. 140 Kodeksu wykroczeń). Studia Prawnicze 2(218): 153-173.

${ }^{81}$ Wyrok SN z 28 sierpnia 1934 r., 3 K. 774/34, Zb. Orz. SN, Orzeczenia Izby Karnej 1935, poz. 73 . 
Kulesza, J. (2020a). Glosa do wyroku Sądu Okręgowego we Wrocławiu z dnia 25 lipca 2019 r., IV Ka 677/19. Państwo i Prawo [przyjęty do druku].

Kulesza, J. (2020b). Publiczne prezentowanie zdjęć martwych płodów przez działaczy pro-life w orzecznictwie sądów powszechnych. Analiza krytyczna, [w:] A. Liszewska, J. Kulesza (red.), Pro dignitate legis et maiestate iustitiae. Księga jubileuszowa z okazji 70. rocznicy urodzin Profesora Witolda Kuleszy. Łódź: 677-700.

Kulesza, J. (2020c). Wybryk nieobyczajny publicznego prezentowania zdjęć martwych płodów a ochrona wolności wypowiedzi w świetle orzecznictwa ETPC. Studia Prawno-Ekonomiczne 114(1) [w druku].

Kurzępa, B. (2008). Art. 51, [w:] Kodeks wykroczeń. Komentarz. [Online] Lex.

Leżański, R.A. (1930). Kodeks karny obowiązujący na ziemiach zachodnich Rzeczypospolitej Polskiej. Poznań.

Makarewicz, J. (1938). Kodeks karny z komentarzem. Lwów.

Makowski, W. (1921). Kodeks karny obowiąujący tymczasowo w Rzeczypospolitej Polskiej na ziemiach b. zaboru rosyjskiego. Tom 2 . Warszawa.

Marek, A. (2008). Prawo wykroczeń (materialne i procesowe). Warszawa.

Mogilnicki, A., Rappaport, E.S. (1928). Ustawy karne tymczasowo obowiązujące w okręgach sadów apelacyjnych w Warszawie, Lublinie i Wilnie. Tom 1: Kodeks karny z ustawami dodatkowemi. Warszawa.

Peiper, L. (1936). Komentarz do Kodeksu karnego, Prawa o wykroczeniach, Przepisów wprowadzających obie te ustawy. Kraków.

Petasz, P. (2018). Charakterystyka znamion strony przedmiotowej i podmiotowej wykroczenia z art. $51 \S 1$ k.w. z 1971 r. Glosa do wyroku Sądu Najwyższego z dnia 30 stycznia 2018 r., IV KK 475/17. Gdańskie Studia Prawnicze - Przegląd Orzecznictwa 14(2): 93-99.

Radecki, W. (1984). Oceny publicznego pijaństwa w prawie wykroczeń, Zagadnienia Wykroczeń 29(2): 45-54.

Radecki, W. (1986). Wybrane zagadnienia części szczególnej prawa wykroczeń, [w:] M. Bojarski, A. Gubiński, W. Radecki, S. Stachowiak, Wybrane zagadnienia materialnego i procesowego prawa o wykroczeniach. Warszawa (wkładka do Zagadnień Wykroczeń 31(4/5): 63-96.

Rappaport, E.S. (oprac.) (1929). Projekt wstępny Ustawy o wykroczeniach. Komisja Kodyfikacyjna Rzeczypospolitej Polskiej. Sekcja Prawa Karnego. Tom 4. Zeszyt 4. Warszawa.

Rappaport, E.S., Lemkin, R. (oprac.) (1931). Projekt wstępny Ustawy o wykroczeniach administracyjnych wraz z sumarycznem uzasadnieniem. Komisja Kodyfikacyjna Rzeczypospolitej Polskiej. Sekcja Prawa Karnego. Tom 5. Zeszyt 7. Warszawa.

Sawicki, J. (1997). Ochrona porządku publicznego w kodeksie wykroczeń i projekcie nowego kodeksu, [w:] Z. Sienkiewicz (red.), Wybrane zagadnienia reformy prawa karnego. Wrocław: 97-112.

Sawicki, J. (2000). Ochrona porządku publicznego w znowelizowanym kodeksie wykroczeń. Nowa Kodyfikacja Prawa Karnego 5: 225-243.

Siewierski, M. (1965). Kodeks karny i Prawo o wykroczeniach. Komentarz. Warszawa.

Tagancew, N. (1922). Kodeks karny. Część II-XIX (art. 73-407). Tłum. J. Dąbrowo, R. Lobman. Warszawa.

\section{PUBLIC PRESENTATION OF PHOTOS OF DEAD FOETUSES \\ AS AN OFFENCE OF PEACE AND PUBLIC ORDER OR SCANDALOUS BEHAVIOUR (ARTICLE 51 PARA. 1 OF THE CODE OF PETTY OFFENCES)}

\section{Sum mary}

The aim of the article is to demonstrate the possibility and validity of classifying the actions of pro-life activists who display photos of dead human foetuses in public spaces as falling under Article 51 para. 1 of the Code of Petty Offences. For this purpose, linguistic, historical, teleological, comparative and systemic interpretation was used. The article demonstrates that presenting large-format pictures of bloody, sometimes fragmented human foetuses on billboards, in public spaces such as streets, squares and parking lots, disturbs public peace, causes a scandal and may 
even disturb public order. The conduct of pro-life activists can also be classed as public indecency. In Poland it is not acceptable, nor is it compatible with common custom or the norms of social coexistence, to impose on people in public spaces photographs of bloody, torn apart human corpses. The intentional conduct of pro-life activists with regard to the actions taken is sufficient to hold them accountable. Yet as described in Article 51 para. 1 of the CoPO, the effects do not have to be intentional; it is enough that they envisaged or at least could have predicted that their actions would disturb the peace or public order, or cause a scandal. For the application of Article 51 para. 1 of the $\mathrm{CoPO}$ it is also enough that the disturbance of peace or public order or a scandal is caused by at least one individual.

Keywords: pro-life activity; photo of human foetus; abortion; misdemeanour; mischief; public peace; public order 
